\title{
Economic Analysis of Prevailing Agroforestry Systems Among Different Categories of Farmers In Kangra Valley of Himachal Pradesh, India
}

\author{
Kaler N. S. , Pant K. S., Gupta B, Bishisht R., Attri V. and Vipasha
}

Dept. of Silviculture and Agroforestry, College of Forestry, Dr. Y.S . Parmar University of Horticulture and Forestry Nauni, Solan, Himachal Pradesh (173 230), India

\section{Corresponding Author}

Kaler N. S.

e-mail: kalernavjot8888@gmail.com

\section{Article History \\ Article ID: AR1828}

Received in $16^{\text {th }}$ July, 2017

Received in revised form $28^{\text {th }}$ July, 2017

Accepted in final form $5^{\text {th }}$ August, 2017

\begin{abstract}
The present study was conducted to evaluate the existing agroforestry systems and economic returns from the systems in Kangra district of Himachal Pradesh, India during the year 2014-15. A total number of 220 farmers were selected randomly from four group's viz., marginal, small, medium and large based on landholding capacity for survey and data collection. The data was collected through pre-tested schedule for the purpose through personal interviews with head of the each household and field sampling. The study revealed that three agroforestry systems types prevalent among different categories of farmers namely: Agri-silviculture (AS), Agri-silvi-horticulture (ASH), Agri-horticulture $(\mathrm{AH})$. The bio economics of the different systems were analyzed by calculating the cost of cultivation, gross returns ha-1, net returns per hectare and benefit:cost ratio. The higher net returns of agroforestry systems among different farmers category was observed maximum in Agri-silviculture (AS), large farmer's category ( $₹$ 240734.32) and benefit:cost ratio of agroforestry systems among farmers category was observed maximum in Agri-silvi-horticulture (ASH), large farmer's category (2.00). Hence the study represents the clear picture of economic analysis of existing agroforestry system which will help the local peoples to fulfil their basic needs and the researchers to gain the benefit from the agroforestry.
\end{abstract}

Keywords: Agroforestry, Biological Yield, Economic Yield, Farmer Categories

\section{Introduction}

Agroforestry is the most important type of farming system which improves the productivity of land on sustainable basis. Existing agroforestry systems in any area is the result of farmers innovation and experimentation over centuries (Rafiq et al., 2000). Agroforestry systems can take an almost infinite number of different forms as they have the potential to include any of the crops, animals and tree species used in agriculture and forestry. This tremendous potential variability allows agroforestry systems to meet the needs of farmers under almost any set of environmental, economic and social conditions and also reduces the risks of farmers' investments as these diversify their crop range and thereby the source of income (Lefroy, 2009). Agroforestry practices can enhance the efficient use of natural resources, increase production (Lott et al., 2000) and quality of food products, raw materials and other kinds of trees and shrubs which leads to assist the farmers by providing a source of livelihood and environmental services (Naiem, 2007). It provides opportunity for diversification of existing land use systems, beneficial environmental impacts and higher returns as compared to sole cropping system (Chaturvedi, 1991). Moreover, in rural areas, agroforestry improves socio-economic conditions by creating job opportunities and provides income, thereby reducing the scarcity of food production and improving financial state (Goudarzian and Yazdani, 2015). As the rapid increase in human population has put tremendous pressure on natural resources, creating an environmental crisis which probably may increase in magnitude in the foreseeable future, the adoption of improved agroforestry systems is one of the alternative mean to counter this ongoing process of resource exploitation and environmental degradation. Agroforestry has gained considerable attention in scientific community which serves as multiple functions and in turn, practitioners have seen these ecological benefits turn into economic benefits through the increase of agricultural output (Hildreth, 2008). Agroforestry plays a vital role in achieving sustainability in the hills farming system (Carson, 1992; Yadav, 1992) and able to satisfy a large diversity of socio-economic needs in a sustainable way. However, there is a need of improvement in agroforestry systems through scientific methods, research etc. so that farmers can generate more economic benefits from agroforestry. Keeping this in view, the study set out to find out 
the economics of existing agroforestry system among different categories of farmers in Kangra district of Himachal Pradesh.

\section{Materials and Methods}

The present study was carried out in the 12 panchayats of Kangra district of Himachal Pradesh, India that lies between $31^{\circ} 41^{\prime}$ to $32^{\circ} 28^{\prime} \mathrm{N}$ latitude and $75^{\circ} 35^{\prime}$ to $77^{\circ} 04^{\prime} \mathrm{E}$ longitude having altitude ranges from 248 to $5861 \mathrm{~m}$ amsl (Figure 1 ). The climate of the district varies from sub-tropical in low hills and valleys to sub-humid in the mid hills and getting temperate in high hills. The average annual rainfall in the district varies from 1500 to $1800 \mathrm{~mm}$. Snowfall is also received in upper ridges of the district. Average minimum and maximum temperature of the district are $3^{\circ} \mathrm{C}$ and $45^{\circ} \mathrm{C}$, respectively.

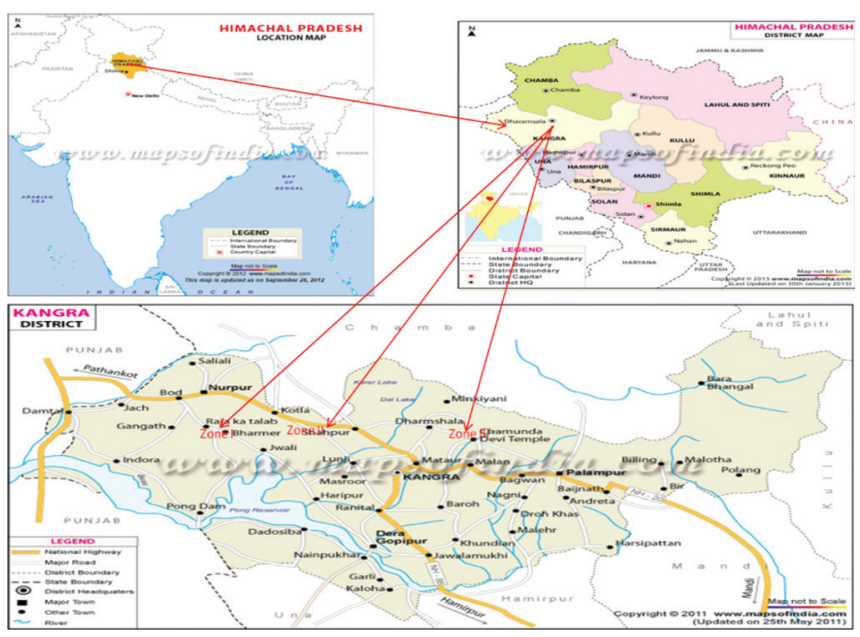

Figure 1: Location map of the study area

From each selected panchayat as per classification of government of Himachal Pradesh, farmers were divided on the basis of their land holding into four different farmers categories: Marginal (<1 ha), Small (1-2 ha), Medium (2-5 ha) and 4 Large ( $>5 \mathrm{ha}$ ) and a random sample of five farmers from each category were taken as ultimate unit of the study. Twenty farmers were falling in each category in each altitudinal zone except large category in altitudinal zone III as there was no farmer found in large category in selected panchayats. In total, 220 farmers were surveyed to know about agroforestry systems practised in the area and their economic was analyzed using.

Bio economics of the system was analyzed by calculating the cost of cultivation, gross and net returns per hectare. All the parameters were calculated on the basis of market price prevailing at the time of completion of the experiment. Cost of cultivation was worked out on per hectare basis as per the prevalent market rates. The prevailing local market price was used to convert the yield of all the crops plants into gross returns in rupees per hectare. Net returns were calculated by deducting total costs from the gross returns:

Net returns $=$ Gross returns-total costs

Benefit: Cost ratio

The net returns per Rupee invested ratio were calculated as per following formula:

Benefit/cost ratio $=\frac{\text { Total discounted benefits }\left(₹ \mathrm{ha}^{-1}\right)}{\text { Total discounted csts }\left(₹ \mathrm{ha}^{-1}\right)}$

\section{Results and discussion}

Irrespective of different categories of farmers, three agroforestry systems types existed in the studied area. The agroforestry systems predominant in Kangra district were Agri-silviculture (AS), Agri-silvihorticulture (ASH) and Agrihorticulture $(\mathrm{AH})$ (Table 1 ). These systems may be attributed to agroclimatic conditions of the area and need of the farmers i.e. food, fodder, fuel wood and timber etc. The identified prevalent agroforestry systems in Lahaul and Kinnaur District (H.P.) were AH, AS, ASP, PS, PH (Anita et al., 2008).

Table 1: Comparative status of various agroforestry system types in different categories of farmers in Kangra District

\begin{tabular}{|c|c|c|c|c|}
\hline \multirow{2}{*}{$\begin{array}{l}\text { Agroforestry system } \\
\text { types }\end{array}$} & \multicolumn{4}{|c|}{ Farmers category (F) } \\
\hline & Marginal & Small & Medium & Large \\
\hline Agri silviculture (AS) & + & + & + & + \\
\hline $\begin{array}{l}\text { Agri silvi horticulture } \\
\text { (ASH) }\end{array}$ & + & + & + & + \\
\hline Agri horticulture $(\mathrm{AH})$ & - & - & + & + \\
\hline
\end{tabular}

+ : Agroforestry System existed; - : Agroforestry system not existed among farmer category

\subsection{Total expenses of agroforestry systems among four farmers category}

Content of the data presented in the Table 2 revealed that the total expenses were significantly influenced by agroforestry systems, farmer's category and their interaction. The

Table 2: Farmers category wise total expenses ( $₹ \mathrm{ha}^{-1} \mathrm{yr}^{-1}$ ) of agroforestry systems in Kangra district

\begin{tabular}{lccccc}
\hline AF systems (S) & \multicolumn{2}{c}{ Farmers category $(F)$} & \multicolumn{2}{c}{ Mean } \\
\cline { 2 - 5 } & Marginal & Small & Medium & 243666.68 \\
\hline AS & 130420.39 & 200169.71 & 233439.36 & 201924.03 \\
ASH & 140758.26 & 200105.00 & 176623.77 & 234494.08 & 187995.28 \\
AH & - & - & 171994.80 & 181688.60 & 176841.70 \\
Mean & 135589.32 & 200137.36 & 194019.31 & 219949.78 \\
\hline
\end{tabular}


significant variation was recorded in the different agroforestry systems for total expenses. The maximum total expenses were noticed in AS system ( $₹$ 201924.03) followed by ASH ( $₹$ 187995.28) while minimum expenses was recorded in the $\mathrm{AH}$ system ( $₹$ 176841.70). The highest total expenses under four farmers categories was observed in large farmer category ( $₹$ 219949.78) and minimum expenses was recorded in marginal farmer category (₹ 135589.32). Highest total expense in large farmer due to higher use of fertilizers, seed cost, irrigation cost, equipment cost etc. The interaction between agroforestry systems and four farmer's categories reported significant variation on the total expenses. The higher total expenses were noticed in the AS, large farmer category ( $₹$ 243666.68) while lower total expenses were recorded in AS, marginal farmer category (₹ 130420.39).

\subsection{Gross return of agroforestry systems among four farmers category}

Results from the Table 3 revealed that the gross return was significantly influenced by agroforestry systems, farmer's category and their interaction. Gross return was found significantly highest in AS system ( $₹$ 394649.37) followed by ASH ( $₹$ 361535.45) whereas on the other hand lowest gross return was found in the $\mathrm{AH}$ system ( $₹$ 330471.40). Among

\begin{tabular}{|c|c|c|c|c|c|}
\hline \multirow[t]{2}{*}{ AF systems (S) } & \multicolumn{4}{|c|}{ Farmers category (F) } & \multirow[t]{2}{*}{ Mean } \\
\hline & Marginal & Small & Medium & Large & \\
\hline AS & 255727.69 & 391583.70 & 446885.09 & 484401.00 & 394649.37 \\
\hline ASH & 260887.57 & 391258.56 & 331364.39 & 462631.26 & 361535.45 \\
\hline $\mathrm{AH}$ & - & - & 319499.46 & 341443.34 & 330471.40 \\
\hline Mean & 258307.63 & 391421.13 & 365916.31 & 429491.86 & \\
\hline
\end{tabular}

four farmers category, the highest significant gross return was reported in large farmer category (₹ 429491.86) while lowest gross return was noticed in marginal farmer category (₹ 258307.63). Interaction between agroforestry systems and four farmer's category significantly influenced the gross return. The maximum gross return was found in AS, large farmer category ( $₹ 484401.00$ ) and lowest gross return was indicated in AS, marginal farmer category ( $₹$ 255727.69) which was found statistically at par with ASH, marginal farmer category ( $₹ 260887.57$ ). The gross returns were found more in agrisiviculture because agriculture crops including cereals, pulses, vegetables etc. are cultivated in large area that fetch more capital to the farmers from market.

\subsection{Net returns of agroforestry systems among four farmers category}

Table 4 revealed that the net returns were significantly influenced by agroforestry systems, farmer's category and their interaction. The highest net returns among agroforestry system was recorded in AS system ( $₹$ 192725.33) followed by ASH (₹ 173540.17) and lowest net returns was recorded in AH system ( $₹ 153629.70)$. Among four farmers category, the highest net returns was observed in large farmer category
(₹ 209542.08), while lowest net returns was found in marginal farmer category ( $₹ 122718.31$ ). Interaction between agroforestry systems and four farmer's category significantly influenced the net returns. The highest net returns in the interaction was occurred in AS, large farmer category ( $₹$ 240734.32), while lowest amount of net return was recorded in ASH, marginal farmer category ( $₹$ 120129.32) which was found statistically at par with AS, marginal farmer category (₹ 125307.30). Higher net returns were associated with financial variables including output prices, establishment cost, labour cost and discount rate. It may also depend on management decisions such as the area planted to crops and trees (Wise and Cacho, 2002).

3.4. Benefit:cost ratio of agroforestry systems among four farmers category

Data evinced (Table 5) that the benefit: cost ratio was significantly influenced by agroforestry systems, farmer's category and their interaction. The maximum benefit: cost ratio among different agroforestry systems was recorded in AS system (1.95) followed by ASH (1.92) and minimum benefit: cost ratio was recorded in $\mathrm{AH}$ system (1.87). Among four farmers category, the highest significant benefit: cost

Table 4: Farmers category wise net returns ( $₹ \mathrm{ha}^{-1} \mathrm{yr}^{-1}$ ) of agroforestry systems in Kangra district

\begin{tabular}{lccccc}
\hline AF systems (S) & \multicolumn{4}{c}{ Farmers category (F) } & \multicolumn{2}{c}{ Mean } \\
\cline { 2 - 5 } & Marginal & Small & Medium & Large \\
\hline AS & 125307.30 & 191413.99 & 213445.73 & 240734.32 & 192725.33 \\
ASH & 120129.32 & 191153.56 & 154740.62 & 228137.18 & 173540.17 \\
AH & - & - & 147504.66 & 159754.74 & 153629.70 \\
Mean & 122718.31 & 191283.77 & 171897.00 & 209542.08 & \\
\hline
\end{tabular}


Table 5: Farmers category wise benefit: cost ratio of agroforestry systems in Kangra district

\begin{tabular}{|c|c|c|c|c|c|}
\hline \multirow{2}{*}{$\begin{array}{l}\text { AF sys- } \\
\text { tems } \\
\text { (S) }\end{array}$} & \multicolumn{4}{|c|}{ Farmers category (F) } & \multirow[t]{2}{*}{ Mean } \\
\hline & Marginal & Small & Medium & Large & \\
\hline AS & 1.95 & 1.96 & 1.92 & 1.98 & 1.95 \\
\hline ASH & 1.89 & 1.95 & 1.86 & 2.00 & 1.92 \\
\hline $\mathrm{AH}$ & - & - & 1.86 & 1.87 & 1.87 \\
\hline Mean & 1.92 & 1.95 & 1.88 & 1.95 & \\
\hline
\end{tabular}

ratio was recorded in small (1.95) and large farmer category (1.95) while on the other hand lowest benefit:cost ratio was found in medium farmer category (1.88). The interaction between agroforestry systems and four farmers category showed significantly higher benefit:cost ratio in ASH, large farmer category (2.00) which were found statistically at par with AS, large (1.98) wheras the lowest benefit: cost ratio was recorded in $\mathrm{ASH}$, medium (1.86) and $\mathrm{AH}$, medium farmer category (1.86) which were found statistically at par with $\mathrm{AH}$, large (1.87) and ASH, marginal (1.89).

\section{Conclusion}

The agrisilviculture (AS) systems was most prevalent and profitable agroforestry systems in Kangra District and also the study revealed that the economic analysis of existing agroforestry system will help the researchers to understand the bioeconomics of agroforestry system in study area in order to make improvement and develop technologies that will help to increase returns from different agroforestry systems.

\section{Acknowledgement}

Authors are thankful to the Prof. B. Gupta, Head of Department, Department of Silviculture and Forestry, College of Forestry, Dr. Y.S. Parmar University of Horticulture and Forestry Nauni (Solan) for providing necessary support. The authors also thank to the line department officials and villagers in the study area for their cooperation during the survey.

\section{References}

Kumari, A., Sehgal, R.N., Kumar, S., 2008. Traditional agroforestry systems practiced in Lahaul (Lahaul and Spiti) and Kinnaur Districts of Himachal Pradesh. Indian Forester, 1003-1010.

Carson, B., 1992. The land, the farmer and the future: a soil fertility management strategies for Nepal. ICIMOD, KTM
Nepal Occasional Paper, No. 2.1.

Chaturvedi, A.N., 1991. Agroforestry in India with particular reference to economic factors. In: Agroforestry in Asia and the Pacific. Mellink, W., Rao, Y.S., McDicken, K.G. (Eds.), Winrock International Institute for Agricultural Development, Regional Office for Asia and the Pacific, Bangkok, 278-287.

Goudarzian, P., Yazdani, M.R., 2015. Climate diversity in line with agroforestry systems: studying technicalities of agroforestry systems and allied components in two diverse climatic regions (Warm climate vs. cold climate) (Case study: Kazeroun and Sepidan in Fars Province, I.R.Iran). Desert 20(2), 157-166.

Hildreth, L.A., 2008. The economic impacts of agroforestry in the Northern Plains of China. Agroforestry Systems $72,119-126$.

Lefroy, E.C., 2009. Agroforestry and the functional mimicry of natural ecosystems. In: Agroforestry for natural resource management (I Nuberg, B George and R Reid eds), CSIRO Publishing, Collingwood, Australia, 21-36.

Lott. J. E., Howard, S.B., Ong, C.K., Black, C.R., 2000. Long-term productivity of a Grevillea robusta-based overstorey agroforestry system in semi-arid Kenya. Forest Ecology and Management 139, 187-201.

Naiem, M., 2007. Preface. In: Sabarnurdin, M.S. (Ed.), The role of agroforestry education in revitalization of agriculture, fishery and forestry program; proceeding international seminar. Gadjah Mada, SEANAFE, Department of Forestry, and Perum Perhutani. Yogyakarta, 7-8 February 2006.

Rafiq, M., Amacher, G.S., Hyde, W.F., 2000. Innovation and adoption in Pakistan's Northwest Frontier Province. In: Economics of Forestry and Rural Development. In: Hyde, W.F., Amacher, G.S. (Eds.), An Empirical Introduction from Asia. Ann Arbor, MI: University of Michigan Press, 87-100.

Wise, R., Cacho, O., 2002. Tree-crop Interactions and their Environmental Economic. Implications in the Presence of Carbon-sequestration Payments, Working Paper CC11, ACIAR Project ASEM 2002/066, Available from: http:/ www.une.edu.au/feb1/Economic/carbon/, accessed June 152006.

Yadav, Y., 1992. Farming-forestry-livestock linkages: a component of mountain farmers' strategies (Nepal). In: Jodha, N.S., Banskota, M., Partap, T. (Eds.), Sustainable Mountain Agriculture. Perspectives and Issues, Vol. 1. Oxford and IBH Publishing Co. Ltd, New Delhi. 